\title{
Identifikasi Virus Hepatitis A pada Sindrom Penyakit Kuning Akut di Beberapa Provinsi di Indonesia Tahun 2013
}

\author{
Eka Pratiwi, Triyani Soekarso, Kindi Adam, Vivi Setiawaty \\ Pusat Penelitian dan Pengembangan Biomedis dan Teknologi Dasar Kesehatan, Badan Penelitian dan \\ Pengembangan Kesehatan, Kementerian Kesehatan Republik Indonesia, Jakarta Pusat, Indonesia
}

\begin{abstract}
Abstrak
Penyakit kuning akut dapat disebabkan oleh infeksi virus hepatitis A, B, C, dan E dengan hepatitis A dan E sebagai penyebab utama wabah. Gejala kuning pada kasus infeksi virus Hepatitis A (HAV) muncul pada 2-6 minggu setelah pasien terinfeksi. Umumnya infeksi HAV tidak akan berkembang menjadi kronis, namun HAV dapat menyebabkan wabah. Pada tahun 2013 terjadi peningkatan penyakit kuning akut pada empat provinsi, yaitu Banten, Kepulauan Riau, Kalimantan Barat, dan Kalimantan Selatan. Penelitian ini bertujuan mengetahui penyebab penyakit kuning akut yang terjadi pada kejadian luar biasa di empat provinsi tersebut. Pengumpulan data dilakukan dari merebaknya kasus penyakit kuning akut selama tahun 2013 di empat provinsi di Indonesia. Spesimen dikumpulkan dan dikirim ke Laboratorium Virologi di Pusat Penelitian dan Pengembangan Biomedis dan Teknologi Dasar Kesehatan (Puslitbang BTDK), Badan Penelitian dan Pengembangan Kesehatan, Kementerian Kesehatan RI. Spesimen diuji antibodi IgM HAV menggunakan metode enzyme immunoassay. Puslitbang BTDK menerima 102 spesimen dari tujuh kali laporan peningkatan kasus di empat provinsi, yaitu Banten, Kalimantan Selatan, Kalimantan Barat, dan Kepulauan Riau. Dari keseluruhan 102 spesimen, 38 spesimen (37\%) positif IgM HAV, meliputi Banten 3 (2,9\%), Kalimantan Selatan 7 (6,9\%), Kepulauan Riau 4 (3,9\%), dan Kalimantan Barat 24 (23,5\%). Lebih banyak kasus perempuan dibanding dengan laki-laki dan dominan pada usia dewasa. Infeksi HAV adalah penyebab sindrom penyakit kuning akut di empat provinsi di Indonesia.
\end{abstract}

Kata kunci: Hepatitis A, penyakit kuning, sindrom

\section{Hepatitis A Virus Identification on Acute Jaundice Syndrome in Some Provinces in Indonesia in 2013}

\begin{abstract}
Acute jaundice can be caused by hepatitis A, B, C and E virus. Hepatitis A and E are often as the main cause of the jaundice outbreak. The symptoms of Hepatitis A virus infection (HAV) appear 2-6 weeks after the patient infected. Generally HAV infection will not develop into chronic stages, but HAV can cause an outbreak. In 2013 there was an increase of acute jaudice syndrome in four provinces that are Banten, Riau Islands, West Kalimantan and South Kalimantan. The study aims to determine the cause of acute jaundice syndrome that occurs in extraordinary events in the four provinces. Data collection was conducted from outbreaks of acute cases of jaundice during 2013 in four provinces in Indonesia. Specimens were collected and sent to the Virology Laboratory at the Center for Research and Development of Biomedical and Basic Health Technology (Puslitbang BTDK), National Institute of Health Research and Development, Ministry of Health. The specimens tested using IgM HAV antibody enzyme immunoassay method. Puslitbang BTDK received 102 specimens from seven extraordinary reports in four provinces namely Banten, South Kalimantan, West Kalimantan and Riau Islands. From all 102 specimens, 38 specimens (37\%) were positive IgM HAV, including Banten 3 (2.9\%), South Kalimantan 7 (6.9\%), Riau Islands 4 (3.9\%) and West Kalimantan 24 (23.5\%). Female cases were more dominant than males. HAV infection is the cause of acute jaundice syndrome in four provinces in Indonesia.
\end{abstract}

Key words: Hepatitis A, jaundice, outbreaks

Korespondensi: Vivi Setiawaty. Puslitbang Biomedis dan Teknologi Dasar Kesehatan, Badan Litbang Kesehatan, Kementerian Kesehatan RI. Jln. Percetakan Negara No. 23, Jakarta Pusat 10560, DKI Jakarta, Indonesia. Telepon: (021) 42887606. HP: o8179804571.E-mail: vilitbang@yahoo.com 


\section{Pendahuluan}

Penyakit kuning akut dapat disebabkan oleh virus hepatitis A, B, C, dan E, sedangkan virus hepatitis A dan E sebagai penyebab utama wabah. Penyakit hepatitis A disebabkan oleh virus hepatitis A atau HAV yang ditularkan melalui feses (fekal-oral). Tidak seperti hepatitis B dan hepatitis C, hepatitis A tidak berkembang menjadi parah dan kronik, tetapi HAV dapat menjadi penyakit infeksi yang mampu menyebabkan kerugian ekonomi yang signifikan dan dapat menyebabkan wabah yang serius berkaitan dengan modus penularan., ${ }^{1,2}$

Masa inkubasi HAV adalah 15-50 hari dengan rata-rata 28 hari sampai dengan 30 hari setelah infeksi. Gejala penyakithepatitis A adalah demam, kelelahan, anoreksia (kehilangan nafsu makan), gangguan pencernaan atau ketidaknyamanan terutama di hati, mual, muntah, urine berwarna teh pekat, serta warna kekuningan pada kulit dan mata (ikterus). ${ }^{3}$ Pada saat penularan, biasanya virus ditemukan di dalam feses dan puncaknya pada 1-2 minggu sebelum timbul gejala, lalu menurun cepat dengan timbul gejala disfungsi hati. Kebanyakan kasus itu tidak menular pada minggu pertama sesudah ikterus. Keberadaan virus dalam feses paling lama 6 bulan pada bayi dan anak. ${ }^{4}$ Ekskresi kronis HAV tidak pernah dilaporkan. Meskipun HAV diekskresikan pada akhir masa inkubasi penyakit, tetapi diagnosis yang spesifik ditentukan oleh deteksi antibodi IgM anti-HAV dalam darah, sedangkan antibodi IgM HAV hanya ada dalam darah 1-2 minggu setelah awal infeksi. ${ }^{5,6}$

Pada tahun 2013, terjadi peningkatan laporan kasus penyakit kuning akut hingga bulan Agustus di Kota Semarang yang diketahui penyebabnya adalah $\mathrm{HAV}^{7,8}$ Beberapa provinsi lainnya juga melaporkan peningkatan kasus penyakit kuning akut dan memerlukan diagnosis penyebab secara laboratorium. Tujuan penelitian ini menentukan penyebab peningkatan kasus penyakit kuning akut tahun 2013 di empat provinsi di Indonesia, yaitu Banten, Kepulauan Riau, Kalimantan Barat, dan Kalimantan Selatan.

\section{Metode}

Pengumpulan data dan spesimen penelitian ini berupa serum didapatkan dari kasus penyakit kuning akut selama tahun 2013 di empat provinsi di Indonesia, yaitu Banten, Kalimantan Barat, Kalimantan Selatan, dan Kepulauan Riau. Serum dikirim oleh puskesmas di kabupaten/kota ke
Laboratorium Virologi di Pusat Penelitian dan Pengembangan Biomedis dan Teknologi Dasar Kesehatan (Puslitbang BTDK), Badan Penelitian dan Pengembangan Kesehatan (Litbangkes), Kementerian Kesehatan RI. Spesimen diperiksa antibodi IgM HAV menggunakan metode enzyme immunoassay. ${ }^{9,10}$ Spesimen disimpan pada suhu $2-8^{\circ} \mathrm{C}$ sampai dengan 7 hari dan untuk waktu yang lama dapat disimpan beku pada suhu $-20^{\circ} \mathrm{C}$.

Spesimen yang dianalisis merupakan serum dari kasus kejadian luar biasa (KLB) tersangka hepatitis A di Indonesia yang terkumpul selama tahun 2013 sebanyak 102 serum. Analisis yang dilakukan adalah deskriptif laboratorium dengan jenis studi potong lintang dan selain parameter deteksi IgM hepatitis A juga melihat persentase kasus hepatitis A di Indonesia. Kasus merupakan bagian dari kegiatan surveilans rutin berbasis kejadian.

\section{Hasil}

Selama tahun 2013 Puslitbang BTDK menerima spesimen penyakit kuning akut sebanyak tujuh kali, yaitu dari Pandeglang-Banten pada bulan Januari dan Juli dengan jumlah 24 spesimen; dari Kota Pontianak pada bulan November dan Desember serta Kabupaten Sintang-Kalimantan Barat selama bulan April dengan jumlah 40 spesimen; Kota Banjarbaru-Kalimantan Selatan pada bulan Februari sebanyak 28 spesimen; dan Kepulauan Riau pada bulan Oktober sebanyak 10 spesimen.

Gambar memperlihatkan hasil tes dari jumlah 102 spesimen didapatkan 38 spesimen (37\%) yang positif antibodi IgM HAV. Hasil positif IgM

\section{Tabel Distribusi Kasus Hepatitis HAV berdasar atas Usia dan Jenis Kelamin}

\begin{tabular}{lrr}
\hline Usia dan Jenis Kelamin & $\begin{array}{r}\text { Kasus } \\
\mathbf{n = 1 0 2}\end{array}$ & \multicolumn{1}{c}{$\%$} \\
\hline Usia (tahun) & & \\
$\quad<6$ & 1 & 1 \\
$6-4$ & 23 & 22,5 \\
$>14$ & 76 & 74,5 \\
N/A & 2 & 2 \\
Jenis kelamin & & \\
Laki-laki & 43 & 42,2 \\
$\quad$ Perempuan & 59 & 57,8 \\
\hline
\end{tabular}




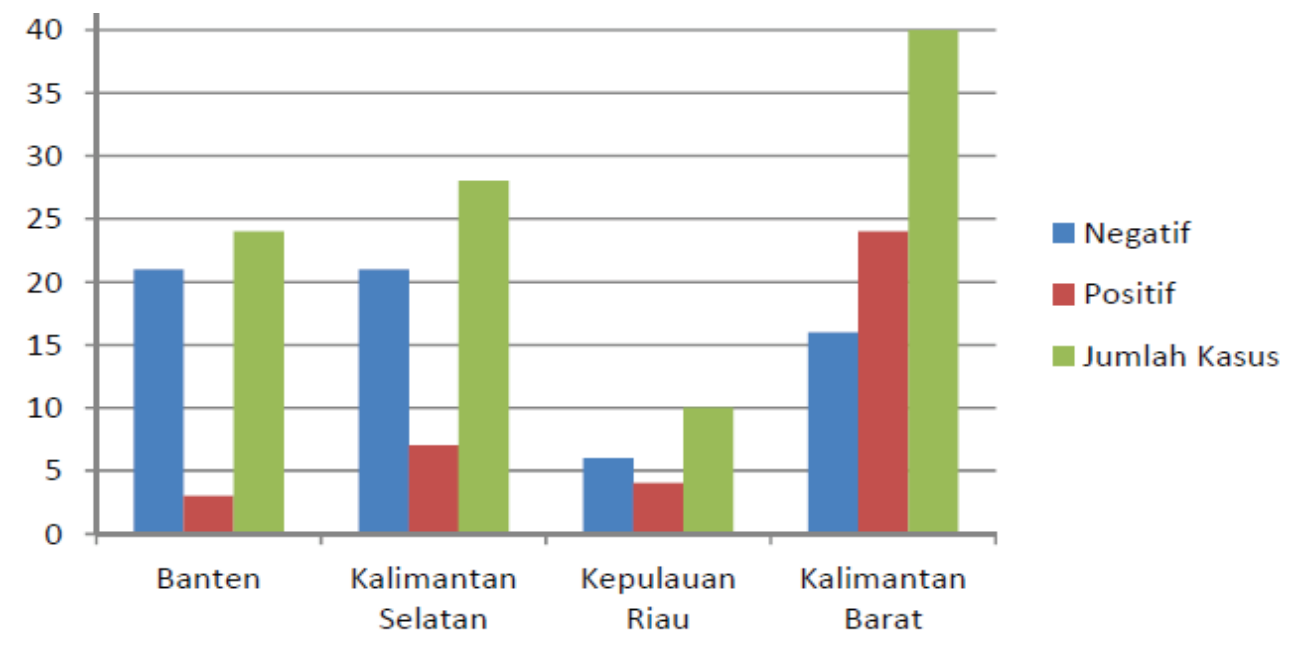

Gambar Hasil Antibodi IgM HAV

sebanyak 38 spesimen yang diperiksa datang dari beberapa provinsi, yaitu 3 spesimen $(2,9 \%)$ dari Banten, 7 spesimen $(6,9 \%)$ dari Kalimantan Selatan, 4 spesimen (3,9\%) dari Kepulauan Riau, dan 24 spesimen (23,5\%) dari Kalimantan Barat.

Tabel memperlihatkan bahwa berdasar atas usia hanya 1 kasus (1\%) yang berusia $<6$ tahun, 23 kasus (23\%) berusia 6-14 tahun, dan sebagian besar 76 kasus (75\%) berusia $>14$ tahun. Hasil ini sesuai dengan WHO bahwa negara-negara berkembang seperti Indonesia infeksi banyak terjadi pada remaja dan orang dewasa. Tabel juga memperlihatkan bahwa persentase kasus penyakit HAV pada wanita yang diperiksa lebih besar dibanding dengan pria (57,8\% vs $42,1 \%$ ).

\section{Pembahasan}

Hepatitis A masih merupakan masalah kesehatan di negara berkembang termasuk Indonesia. ${ }^{11}$ Berdasar atas data yang berasal dari rumah sakit, hepatitis A masih merupakan bagian terbesar kasus hepatitis akut yang dirawat, yaitu berkisar 39,8-68,3\%. ${ }^{12}$ Incidence rate (IR) hepatitis per 10.000 populasi sering kali berfluktuasi selama beberapa tahun silam. Suatu studi di Jakarta melaporkan bahwa anti-HAV dapat ditemukan pada bayi baru lahir dan ditemukan pada $20 \%$ bayi. Angka prevalensi ini terus meningkat pada usia di atas 20 tahun. ${ }^{13}$ Hal ini sesuai dengan kasus penyakit kuning akut dari empat provinsi yang kasus terbanyak berusia di atas 14 tahun.

Data prevalensi hepatitis berdasar atas hasil Riskesdas menunjukkan bahwa pada tahun 2013 secara nasional diperkirakan $1,2 \%$ penduduk di Indonesia mengidap penyakit hepatitis dan kondisi ini meningkat dua kali lipat dibanding dengan tahun 2007, yaitu sekitar 0,6\%. Apabila dikonversikan ke dalam jumlah absolut penduduk Indonesia tahun 2013 sekitar 248.422.956 jiwa maka dapat dikatakan bahwa 2.981.075 jiwa penduduk Indonesia terinfeksi hepatitis. ${ }^{14}$

Diperkirakan terdapat sekitar 1,5 juta kasus klinis dari hepatitis A terjadi di seluruh dunia setiap tahunnya, tetapi rasio infeksi hepatits A yang tidak terdeteksi dapat mencapai sepuluh kali lipat daripada jumlah kasus klinis tersebut. Indonesia menempati urutan yang ketiga setelah India dan China. ${ }^{15}$ Seroprevalensi HAV beragam dari beberapa negara di Asia. Korea, Indonesia, Thailand, Srilanka, dan juga Malaysia merupakan negara dengan endemisitas sedang. Data yang tersedia menunjukkan rasio insidensi mungkin mengalami penurunan di wilayah perkotaan dan usia pada saat infeksi meningkat dari awal masa kanak-kanak menuju ke akhir masa kanak-kanak akan meningkatkan risiko terjadi wabah HAV. Angka kejadian hepatitis A di Amerika Serikat telah turun sebanyak 95\% sejak vaksin HAV pertama kali tersedia pada tahun 1995. Pada tahun 2010 dilaporkan 1.670 kasus HAV akut dengan IR sebanyak 0,6/100.000, rasio terendah yang pernah tercatat. Setelah disesuaikan dengan infeksi asimtomatik dan juga kejadian yang tidak dilaporkan, perkiraan jumlah infeksi baru sekitar 17.000 kasus. ${ }^{16-18}$

Virus hepatitis A itu merupakan penyebab penting hepatitis virus akut, terutama di negara berkembang. Penularan virus hepatitis A dapat terjadi dengan cara kontak antara orang ke orang 
(kontak di rumah, di tempat penitipan anak, pesantren, dan asrama) atau melalui makanan dan air yang tercemar tinja yang mengandung virus hepatitis A. ${ }^{6}$ Pada anak penyakit ini biasanya subklinis anikterik, sedangkan pada dewasa yang disebabkan oleh HAV lebih ke hepatitis ikterik. Tanda dan gejala hepatitis A meliputi kelelahan, mual dan muntah, merasa perut tidak nyaman, kehilangan nafsu makan, demam ringan, nyeri otot, dan juga sakit kuning. Semua suspek yang dikirim spesimennya memiliki gejala yang sama di antaranya lemah, kurang nafsu makan, warna kuning pada kulit dan putih mata, serta demam ringan dan gatal menyebar. ${ }^{19}$

Penyakit ini berkaitan erat dengan lingkungan dan sanitasi yang bersih dari tiap individu. Suplai air bersih yang adekuat dengan pembuangan kotoran yang baik dan benar di dalam komunitas, dikombinasikan dengan praktik higiene personal yang baik, seperti secara teratur mencuci tangan dapat mengurangi penyebaran penyakit HAV. Setiap orang rentan terhadap infeksi. Imunitas dapat diperoleh dengan cara kekebalan yang didapat setelah infeksi. Ketika antibodi terbentuk, anti-HAV dapat bertahan seumur hidup. Dapat juga memperoleh kekebalan setelah pemberian imunisasi HAV. ${ }^{20}$

Pencegahan lainnya dapat dengan pemberian imunisasi pasif dengan imunoglobulin normal atau immune serum globulin prophylaxis dapat efektif dan memberi perlindungan selama tiga bulan. Akan tetapi, dengan penemuan vaksin yang sangat efektif maka imunoglobulin tersebut menjadi jarang dipergunakan. Imunisasi pasif ini diindikasikan untuk turis yang berkunjung ke daerah endemik dalam waktu singkat, wanita hamil, orang yang dilahirkan di daerah endemis HAV, orang dengan immunocompromised yang mempunyai risiko penyakit berat setelah kontak erat, dan para pekerja kesehatan setelah terpajan akibat pekerjaan. Bilamana sumber infeksi HAV teridentifikasi, contohnya makanan atau air yang terkontaminasi HAV, immune serum globulin prophylaxis harus diberikan kepada siapa saja yang telah terpapar dari kontaminan tersebut. ${ }^{21}$ Hal ini terutama berlaku untuk wabah HAV yang terjadi di sekolah, rumah sakit, penjara, dan institusi lainnya. Imunisasi aktif dengan vaksin mati memberikan imunitas yang sangat baik. Imunisasi ini diindikasikan untuk para turis yang berkunjung ke daerah endemik untuk memusnahkan wabah dan melindungi pekerja kesehatan setelah pajanan atau sebelum pajanan bila terdapat risiko akibat pekerjaan. Vaksinasi
HAV memberikan kemanjuran proteksi terhadap penyakit HAV sebesar 94\% sampai 100\% setelah 2-3 dosis suntikan diberikan 6-12 bulan secara terpisah dengan efek samping yang minimal..$^{16,18}$

Spesimen yang diperlukan merupakan serum kasus yang diambil sesudah kasus dirawat di fasilitas kesehatan. IgM anti-HAV terdeteksi tiga minggu setelah paparan dan titer IgM anti-HAV itu akan terus meningkat selama 4-6 minggu, lalu akan terus turun sampai level yang tidak terdeteksi dalam waktu 6 bulan infeksi. IgA dan IgG anti-HAV dapat dideteksi dalam beberapa hari setelah timbulnya gejala. Antibodi IgG akan bertahan selama bertahun-tahun setelah infeksi dan memberikan imunitas seumur hidup. ${ }^{22}$

Deteksi antibodi tersebut dapat dilaksanakan dengan rapid test memakai metode immunochromatographic assay dengan alat diagnosis komersial yang telah tersedia. Alat diagnosis ini memiliki tiga garis yang telah dilapisi oleh antibodi, yaitu "G" (HAV IgG test line), "M" (HAV IgM test line), dan "C" (control line) yang terletak pada permukaan membran. Garis "G" dan " $M$ " berwarna ungu akan timbul pada jendela hasil apabila IgG dan/atau IgM anti-HAV kadarnya cukup pada sampel. ${ }^{23}$ Menggunakan rapid test dengan metode immunochromatographic assay didapatkan spesifisitas mendeteksi IgM antiHAV hingga keakuratan 98,0\% dengan tingkat sensitivitas hingga 97,6\%.24 Identifikasi cepat dan pelaporan segera kasus hepatitis A sangatlah penting untuk dapat mencegah penularan pada masyarakat yang lebih luas. ${ }^{25}$

\section{Simpulan}

Penyebab beberapa kasus penyakit kuning akut yang terjadi di empat provinsi di empat provinsi di Indonesia, yaitu Banten, Kalimantan Selatan, Kepulauan Riau, dan juga Kalimantan Barat pada tahun 2013 adalah infeksi virus hepatitis A

\section{Ucapan Terima Kasih}

Pemeriksaan laboratorium untuk diagnosis HAV dilakukan menggunakan dana dari Badan Litbang Kesehatan. Ucapan terima kasih kepada Kepala Puslitbang Biomedis dan Teknologi Dasar Kesehatan dan Koordinator Laboratorium, Drs. Bambang Heriyanto, M.Kes. yang telah memberi dukungan pada kegiatan ini. Ucapan terima kasih juga kami haturkan kepada Petugas Dinas Kesehatan Kabupaten untuk bantuan mereka dalam melengkapi data kasus. 


\section{Daftar Pustaka}

1. Godoy P, Broner S, Manzanares-Laya S, Martínez A, Parrón I, Planas C, dkk. Outbreaks of hepatitis A associated with immigrants travelling to visit friends and relatives. J Infect. 2016;72(1):112-5.

2. Ghasemian A. Prevalence of hepatitis A across various countries in the Middle East, African and Eastern European countries. Caspian J Intern Med. 2016;7(4):302-3.

3. Fares A. Seasonality of hepatitis: a review update. J Family Med Prim Care. 2015;4(1):96-100.

4. Lee HW, Chang DY, Moon HJ, Chang HY, Shin EC, Lee JS, dkk. Clinical factors and viral load influencing of acute hepatitis A. PLoS One. 2015;10(6):e0130728.

5. Vivek R, Zachariah UG, Ramachandran J, Eapen CE, Rajan DP, Kang G. Characterization of hepatitis $\mathrm{E}$ virus from sporadic hepatitis cases and sewage samples from Vellore, south India. Trans R Soc Trop Med Hyg. 2013;107(6):363-7.

6. Direktorat Jenderal Pengendalian Penyakit \& Penyehatan Lingkungan, Kementerian Kesehatan RI. Pedoman pengendalian hepatitis virus. Jakarta: Ditjen PP \& PL, Kemenkes RI; 2012.

7. Pusat Data dan Informasi, Kementerian Kesehatan RI. Situasi dan analisis hepatitis. Jakarta: Kemenkes RI; 2014.

8. Dinas Kesehatan Kota. Hepatitis. Semarang: Dinkes Provinsi Jawa Tengah; 2013.

9. Center for Disease Control and Prevention, National Notifiable Diseases Surveillance System (NNDSS). Hepatitis A, acute: 2012 case definition [diunduh 13 September 2017]. Tersedia dari: https://wwwn.cdc.gov/ nndss/conditions/hepatitis-a-acute/casedefinition/2012.

10. ARUP Laboratories. Hepatitis virus screening algorithm. 2014 [diunduh 13 September 2017]. Tersedia dari: https://arupconsult. com/algorithm/hepatitis-virus-screeningalgorithm.

11. Jacobsen KH, Wiersma ST. Hepatitis A virus seroprevalence by age and world region, 1990 and 2005. Vaccine. 2010;28(41):6653-7.

12. Cahyono JBSB. Hepatitis A: cegah penularannya. Yogyakarta: Penerbit Kanisius; 2009.

13. Badan Penelitian dan Pengembangan
Kesehatan, Kementerian Kesehatan Republik Indonesia. Riset kesehatan dasar (Riskesdas) 2010. Jakarta: Badan Penelitian dan Pengembangan Kesehatan, Kemenkes RI; 2010.

14. Badan Penelitian dan Pengembangan Kesehatan, Kementerian Kesehatan Republik Indonesia. Riset kesehatan dasar (Riskesdas) 2013. Jakarta: Badan Penelitian dan Pengembangan Kesehatan, Kemenkes RI; 2013.

15. World Health Organization. Global alert and response (GAR): hepatitis A. 2017 [diunduh 13 September 2017]. Tersedia dari: http://www.who.int/csr/disease/hepatitis/ whocdscsredc2007/en/index4.html\#.

16. Bawazir AA, Hart CA, Sallam TA, Parry CM, Beeching NJ, Cuevas LE. Seroepidemiology of hepatitis A and hepatitis $\mathrm{E}$ viruses in Aden, Yemen. Trans R Soc Trop Med Hyg. 2010;104(12):801-5.

17. Klevens RM, Miller JT, Iqbal K, Thomas A, Rizzo EM, Hanson H, dkk. The evolving epidemiology of hepatitis a in the United States: incidence and molecular epidemiology from population-based surveillance, 20052007. Arch Intern Med. 2010;170(20):18118.

18. Daniels D, Grytdal S, Wasley A; Centers for Disease Control and Prevention (CDC). Surveillance for acute viral hepatitis - United States, 2007. MMWR Surveill Summ. 2009;58(3):1-27.

19. Bohm SR, Berger KW, Hackert PB, Renas R, Brunette S, Parker N, dkk. Hepatitis A outbreak among adults with developmental disabilities in group homes--Michigan, 2013. MMWR. 2015;64(6):148-52.

20. Wang Z, Chen Y, Xie S, Lv H. Changing epidemiological characteristics of hepatitis A in Zhejiang Province, China: increased susceptibility in adults. PLoS One. 2016;11(4):e0153804.

21. Roque-Afonso AM, Mackiewicz V, Dussaix E. Detection of immunoglobulin M antibody to hepatitis A virus in patients without acute hepatitis A: the usefulness of specific immunoglobulin $\mathrm{G}$ avidity. Clin Infect Dis. 2006;42(6):887-8.

22. Advisory Committee on Immunization Practices (ACIP), Fiore AE, Wasley A, Bell BP. Prevention of hepatitis A through active or passive immunization: recommendations of the Advisory Committee on Immunization 
204 Eka Pratiwi dkk.: Identifikasi Virus Hepatitis A pada Sindrom Penyakit Kuning Akut di Beberapa Provinsi di Indonesia

Practices (ACIP). MMWR Recomm Rep. 2006;55(RR-7):1-23.

23. Ly KN, Klevens RM. Trends in disease and complications of hepatitis A virus infection in the United States, 1999-2011: a new concern for adults. J Infect Dis. 2015;212(2):176-82.

24. Wiseman R, Weil LM, Lozano C, Johnson TJ Jr, Jin S, Moorman AC, dkk. Notes from the field: health care-associated hepatitis A outbreak - Texas, 2015. MMWR. 2016;65(16):425-6.

25. Klevens RM, Sharapov U. Chapter 3: hepatitis A. Dalam: Roush SW, Baldy LM, penyunting. Centers for Disease Control and Prevention's manual for the surveillance of vaccine-preventable diseases. Edisi ke-5. Atlanta, Georgia: Centers for Disease Control and Prevention; 2011. 